\title{
Freedom of Religion or Belief and Employment Law
}

\author{
Lucy Vickers
}

Professor of Law, Oxford Brookes University, United Kingdom

\begin{abstract}
This article explores the extent to which the jurisprudence of the European Convention on Human Rights has promoted the protection of freedom of religion or belief in the context of the workplace since the decision in Kokkinakis v. Greece. As a preliminary question it explores whether and why freedom of religion or belief extends to the employment relationship. It then considers two main areas where freedom of religion or belief interacts with employment: the rights of religious workers to manifest religion or belief at work, and the rights of religious organisations to impose religious requirements on their staff.
\end{abstract}

\section{Keywords}

freedom of religion or belief - Article 9 - employment - workplace - religious symbols European Convention on Human Rights - European Court of Human Rights 
Although the right to freedom of religion is granted extensive protection within the European Convention on Human Rights (ECHR) the extent to which this right is protected at work has not been so clear. For many years since Kokkinakis the former European Commission of Human Rights (ECommHR) and the European Court of Human Rights (ECtHR) continued to take the restrictive view, formulated prior to Kokkinakis and in respect of a different Convention article, that the ECHR did not protect a right to a job; thus interferences with Convention freedoms at work were not viewed as infringing the Convention. Only in 2013 did the ECtHR signal a clear change to this approach, although prior to this there had been some implied and incremental changes. In this article, I explore two main areas where freedom of religion or belief interacts with employment: religious workers' rights to manifest religion or belief at work; and religious organisations' rights to impose religious requirements on their staff. First, I consider the preliminary questions of whether and why freedom of religion or belief extends to the employment relationship.

\section{Why Should Religious Interests be Protected at Work?}

As Kokkinakis famously put it, freedom of religion or belief is one of the foundations of a 'democratic society', and one of the 'most vital elements that go to make up the identity of believers and their conception of life'. ${ }^{1}$ That religious freedom and pluralism is indissociable from democratic society is not disputed: but what has not been so clear is the extent to which these freedoms are protected in the workplace. ${ }^{2}$ Two main reasons can be given for limiting protection: first, religiously observant employees are not obliged to infringe their conscience but can walk away or resign; second, in any event, most restrictions on religion that arise at work involve the manifestation of religion or belief, and under Article 9 ECHR this freedom can be restricted where necessary to safeguard the rights of others, such as the employer, customer or colleagues.

There are two major reasons why religion or belief should, nonetheless, be protected

\footnotetext{
${ }^{1}$ Kokkinakis v. Greece, Application No. 14307/88, judgment of 25 May 1993, at para. 31.

2 These issues are discussed in more detail in Lucy Vickers, Religious Freedom, Religious Discrimination and the Workplace (Oxford: Hart Publishing, 2016), Chapter Three.
} 
in the workplace. ${ }^{3}$ First, if freedom of religion and belief is to be given practical protection, it must be operable in common areas of daily life, including professional life. Otherwise, religion and belief becomes relegated to the private sphere, and the freedom to manifest 'in public' is restricted. ${ }^{4}$ Second, to confine the protection of freedom of religion or belief to the world outside of work results in uneven treatment as between different beliefs: ${ }^{5}$ some religions have few practices which impact at work; others have rules such as dress codes or working times which can interfere with the usual rules of the workplace. Thus, limiting protection for religion or belief to the non-work sphere will result in some religious groups remaining free to engage in employment, while others, often from minority religions, are less able to access the many financial and other benefits of work.

Given the recognition in Kokkinakis of the importance of freedom of religion or belief to individual identity it is perhaps unsurprising that the ECtHR has made some progress in providing some level of protection for religion in the workplace. However, as is discussed below, that progress has been somewhat hindered by the deference showed to individual states in the application of the Convention in individual cases through the operation of the margin of appreciation doctrine.

\section{The Application of the ECHR to the Workplace}

Prior to Kokkinakis, the ECtHR had considered the preliminary question of whether Convention rights survived entry to the workplace in the context of the Article 10 right to freedom of expression; the conclusion was, at first, that rights were not so protected, but that instead that Convention rights were protected by a right to resign.

The idea that the right to resign can act as a safeguard for rights can be seen in the pre-Kokkinakis Article 10 cases, Kosiek v. Germany, ${ }^{6}$ and Glasenapp v. Germany, ${ }^{7}$ where employees lost their freedom of expression claims when they were refused employment because of their active membership of extreme political parties. In these cases the ECtHR effectively held that Convention rights do not apply at work, because of the freedom of the

\footnotetext{
${ }^{3}$ See Anthony Bradney, Religions, Rights and Laws (Leicester: Leicester University Press, 1993)

${ }^{4}$ This of course begs the question of whether the workplace is a public or private space, discussed further in Lucy Vickers, Religious Freedom, Religious Discrimination and the Workplace (Oxford: Hart Publishing, 2016), Chapter Three.

${ }^{5}$ Megan Pearson, 'Religious Discrimination and the 'Hierarchy of Rights': Non-Existent, Appropriate or Problematic?,' 16 (1) International Journal of Discrimination and the Law (2016), pp. 37-50.

${ }^{6}$ Application No. 9704/82, judgment of 28 August 1986.

${ }^{7}$ Application No. 9228/80, judgment of 28 August 1986.
} 
individual to resign. As a result, these cases fell at the first hurdle.

The 'right to resign' was also used in two Article 9 cases, Ahmad v. UK ${ }^{8}$ and Stedman v. $U K,{ }^{9}$ involving dismissals for refusing to work in order to attend, respectively, prayers and church. In both cases the ECommHR again took the view that there was no breach of Article 9: the employee was free to resign. This approach was repeated as late as 2012 in Sessa v. Italy ${ }^{10}$ where a court refused to adjourn a case hearing when the proposed dates clashed with major Jewish religious festivals, because the applicant was still free to fulfil his religious duties. ${ }^{11}$ The idea that freedom to leave one's job can provide adequate rights protection had created a significant barrier to the protection of religion or belief in the workplace.

However, the ECtHR has not been entirely consistent it is application of this rule, and some softening of the rule can be seen, starting in cases involving other Convention rights such as Article 8 and Article 10. In 1996, in Vogt v. Germany, ${ }^{12}$ the ECtHR decided that dismissal of a teacher for her political activity infringed with her right to freedom of expression, on the basis that that work-based restrictions are significant interferences with rights. In Niemietz v. Germany, ${ }^{13}$ and Sidabras v. Lithuania, ${ }^{14}$ the ECtHR confirmed that Article 8 rights were protected in the workplace, on the basis that work is not a separate part of life but is a sphere in which human rights require some protection. Latterly, a shift, although not explicit, could be perceived on this issue in the context of Article 9. In Saniewski v. Poland ${ }^{15}$ the ECtHR suggested that an employment related penalty could amount to an interference with the right to freedom of religion; and in Pitkevich v. Russia ${ }^{16}$ the ECtHR found that the dismissal of a judge for the expression of her religious views involved a prima facie interference with her rights under Article 9 (although the dismissal was found to be proportionate on its facts).

Finally, in 2013 in the case of Eweida and Others v. $U K^{17}$ the ECtHR explicitly held that the freedom to resign provides inadequate protection for religious freedom, and that religion or belief can be protected within the workplace. The cases involved four employees who claimed that they had been discriminated against at work because of their manifestation

\footnotetext{
${ }^{8}$ Ahmad v. UK Application No. 8160/78, judgment of 12 March 1981.

${ }^{9}$ Stedman v. UK Application No. 29107/95, judgment of 9 April 1997.

${ }^{10}$ Application No. 28790/08, 3 April 2012.

${ }^{11}$ Sessa, at para. 37.

${ }^{12}$ Vogt v. Germany, Application No. 17851/91, judgment of 2 September 1996.

${ }^{13}$.Niemietz v. Germany, Application No. 13710/88, judgment of 16 December 1992.

${ }^{14}$ Sidabras and Dziautas v. Lithuania, Application Nos. 55480/00 \& 59330/00, judgment of 27 July 2004.

15 Saniewski v. Poland Application No. 40319/98, judgment of of 26 June 2001.

${ }^{16}$ Pitkevich v. Russia Application No. 47936/99, judgment of 8 February 2001.

${ }^{17}$ Applications nos. 48420/10, 59842/10, 51671/10 and 36516/10, judgment of 15 January 2013.
} 
of religion. Referring to Vogt and the developments in the Court's case law in the context of other rights, the Court held that:

where an individual complains of a restriction on freedom of religion in the workplace, rather than holding that the possibility of changing job would negate any interference with the right, the better approach would be to weigh that possibility in the overall balance when considering whether or not the restriction was proportionate. ${ }^{18}$

This seems to be a significant step towards greater protection of freedom of religion or belief in the workplace. The Court clearly accepts that work-based restrictions on a person's exercise of religious freedom can amount to a prima facie infringement of the right to freedom of religion or belief.

However, while a welcome decision, it would be premature to conclude that since Eweida the Strasbourg court now successfully protects what Kokkinakis termed a 'precious asset', freedom of religion or belief. This is because although the first hurdle in making a claim for freedom of religion or belief in employment has been largely removed, workers are still faced with further hurdles before a claim will be successful. A religious practice will need to be seen as a manifestation of religion; and then it will be necessary to show that any restriction on the practice is not justified under the Article 9(2).

\section{$4 \quad$ Manifestation of Religion or Belief at Work}

It is the manifestation of belief which is most likely to be the cause of interference with freedom of religion or belief in the work context, with many claims involving religious dress or time off for religious observance. The question of whether an employer may be required to accommodate religious practices by staff will depend in part on whether the practices are viewed in law as manifestations of religion. The distinction traditionally drawn in ECHR jurisprudence between manifestations of religion on the one hand, and activities which are merely 'religiously motivated' on the other, ${ }^{19}$ could cause problems in the work context because if behaviour is not required by religion as part of religious observance, it could be

\footnotetext{
${ }^{18}$ Eweida, at para. 83 .

${ }^{19}$ Arrowsmith v. UK Application No. 7050/75, judgment of 5 December 1978; Pichon and Sajous v. France, Application No. 49853/99, judgment of 2 October 2001.
} 
restricted by an employer without engaging Article 9.

The restrictive approach of the court on this issue can be strongly criticised, not least because it means that cases are lost before the proportionality of restrictions can be considered. It can also involve courts in determining matters of religious doctrine which are inappropriate for resolution by secular courts. However, in Eweida et al v. UK ${ }^{20}$ the Court took a much more flexible approach to the issue of manifestation of religion than had been seen in earlier cases. Whilst recognising that there is a distinction between acts 'remotely connected to a precept of faith', and acts that are 'intimately linked to the religion or belief', ${ }^{21}$ such as the act of worship, it confirmed that 'the manifestation of religion or belief is not limited to such acts' and that 'there is no requirement on the applicant to establish that he or she acted in fulfilment of a duty mandated by the religion in question'. Instead, there needs only be 'the existence of a sufficiently close and direct nexus between the act and the underlying belief ... determined on the facts of each case. ${ }^{22}$

The acceptance by the Court that the manifestation of religion can include a much wider range of activities than those strictly required by religion is to be welcomed as it extends the potential for the ECHR to provide protection for freedom of religion or belief, and allows Courts to proceed to the question of whether restrictions are proportionate, rather than being caught at the preliminary step of establishing either that the workplace is a proper sphere for the protection of religion or belief, or that the religious practice in question is not a manifestation of religion.

\section{$5 \quad$ Justifying Restrictions on Religion or Belief at Work}

Under Article 9(2) limitations on the manifestation of religion are allowed as long as they serve a legitimate aim, and are necessary and proportionate to the achievement of that aim. It is relatively easy to establish a legitimate aim for restrictions on religion or belief at work, not least because of the clear rights of employers to managerial discretion in the running of the business and the rights of other staff to work in an environment in which their equality and dignity are respected. Given that this is a relatively simple hurdle to cross, much will depend on whether any restriction is necessary and proportionate. At this stage, the decision will be

\footnotetext{
${ }^{20}$ Eweida ibid.

${ }^{21}$ At para. 82.

${ }^{22}$ At para. 82 .
} 
fairly dependent on the facts of the individual case. The case law which has developed since Kokkinakis suggests that factors such as the nature of the restriction on religion, ${ }^{23}$ the nature of the applicant's job, ${ }^{24}$ the relationship between the religious expression and the applicant's job, ${ }^{25}$ and the nature of the religious belief itself ${ }^{26}$ will influence the outcome of the Court's proportionality assessment. The ECtHR has also recognised that states need a certain flexibility in their observance of the Convention, and has established the concept of the 'margin of appreciation', which gives states flexibility in the interpretation of the Convention and in setting the parameters of their domestic law. In religion cases the ECtHR has allowed a fairly wide margin to operate, ${ }^{27}$ and although this reflects the lack of consensus across Europe about how religion should be treated, the effect is to allow significant differences in the level of protection afforded to freedom of religion or belief.

The implications of the margin of appreciation doctrine to the employment context can be seen in the cases on religious symbols at work. In Eweida, two workers, Ms Eweida and Ms Chaplin, were dismissed for wearing a cross at work. The restriction which was imposed on Ms Eweida aimed to uphold a particular corporate image, and was found to breach Article 9; the restriction imposed on Ms Chaplin aimed to meet health and safety concerns and did not breach Article 9. The recognition in Eweida that corporate image was insufficient to justify the restriction on freedom of religion or belief seemed to point to greater protection for religion or belief in the employment context. However, soon after in Ebrahimian v. France 28 another decision of a Chamber of the ECtHR reverted to a more restrictive approach to religious symbols at work, relying heavily on the margin of appreciation. The case concerned a hospital social worker whose contract was not renewed after she had refused to stop wearing a head covering at work. The Court held that Ebrahimian's freedom of religion was not violated. In reaching this decision, the Court noted the lack of consensus across Europe on the issue and the national context of the case, including the principle of secularism in the French Constitution, and the secular nature of the state and the public service.

These cases show that although freedom of religion or belief does now survive entry to the workplace, following the development of the case law and culminating in Eweida, nonetheless, its full protection remains precarious and dependent on the inherent uncertainty

\footnotetext{
${ }^{23}$ Lingens v. Austria, Application No. 9815/82, judgment of 8 July 1986.

${ }^{24}$ Pitkevich v. Russia, Application No. 47936/99, judgment of 8 February 2001.

${ }^{25}$ Larissis v. Greece, applications nos. 140/1996/759/958 960, judgment of 24 February 1998.

${ }^{26}$ Kalaç v. Turkey, Application No. 61/1996/680/870, judgment of 1 July 1997.

${ }^{27}$ Carolyn Evans, Freedom of Religion under the ECHR (Oxford: Oxford University Press, 2001), pp. $143-44$.

${ }^{28}$ Application No. 64846/11, judgment of 26 November 15.
} 
of the margin of appreciation. While respect is needed for the lack of consensus over religion or belief in Europe, its generous use in the employment context does allow for very different levels of protection for freedom of religion or belief in the workplaces of Europe.

\section{Freedom of Religion or Belief: Religious Organisations as Employers}

A second context in which freedom of religion or belief interacts with employment is where religious organisations act as an employer. A wide range of employment is provided by religious organisations in sectors such as education, and health and social care. In some cases the employers are religious organisations such as churches; in other cases they may be small private businesses which the business owner seeks to run along religious lines. Article 9 is clear that the autonomy of religious groups should be respected, for example, in determining their own leadership. ${ }^{29}$ This means the imposition by religious organisations of religious requirements on priests or other religious leaders is likely to be lawful, ${ }^{30}$ but it has been less clear whether this will be the case in respect of religious requirements imposed on other staff.

A number of cases show clear support under the Convention for religious organisations to enjoy some autonomy in their employment practices, although most of these cases have been brought under Articles 8 (right to private life) and 10 (freedom of expression). In Rommelfanger v. $F D R,{ }^{31}$ for example, a doctor in a Roman Catholic hospital was dismissed for publicly disapproving of the Church's attitude to abortion. The ECommHR was clear that the employer was able to set requirements on staff that they comply with the employer's religious ethos, and that the dismissal did not infringe the employee's right to freedom of expression. This approach is followed in later cases from Germany, Obst and Schüth ${ }^{32}$ involving decisions by religious organisations to dismiss staff for failing to comply with religious teaching: in both cases staff members had been involved in extra-marital affairs. The Court reached different decisions, based on procedural aspects of the facts, but did accept as legitimate the imposition of religious lifestyle rules on staff members. Schüth involved a Catholic Church organist and Obst the Director of European Public Relations for

\footnotetext{
${ }^{29}$ See Hasan and Chaush v. Bulgaria, Application No. 30985/96, judgment of October 26 2000, at para. 62; and Serif v. Greece, Application No. 38178/97 judgment of 14 December 1999.

${ }^{30}$ Knudsen v. Norway, Application No. 11045/84, judgment of 8 March 1985.

${ }^{31}$ Application no. 12242/86, judgment of 6 September 1989.

32 Obst v. Germany, Application No. 425/03, judgment of 23 September 2010; Schüth v. Germany, Application No. 1620/03, judgment of 23 September 2010.
} 
the Mormon Church. The ECtHR upheld the claim of the Catholic organist but rejected the claim of the Morman PR Director. The decisions can appear contradictory but the reason for the difference in treatment of the two cases related to the fact that in one case the right to private life had been considered by the decision makers, and in the other it had not. The Court accepted in both cases the legitimacy of the religious ethos employer imposing religious requirements on its staff.

Similarly in Fernández Martinez v. Spain, ${ }^{33}$ involving the decision not to renew the employment contract of a priest who was married and had five children, the ECtHR relied on procedural questions to find that the Spanish courts had reached a fair balance between interests in private life, freedom of religion and freedom of association, and that therefore there had been no violation of Article 8. Again, the legitimacy of imposing rules on staff employed by religious ethos organisations was accepted.

A similarly procedural approach was taken in one case involving Article 9, Siebenhaar v. Germany, ${ }^{34}$ where a member of the Universal Church/Brotherhood of Humanity was dismissed from her post as a teacher in a church kindergarten. Again, the Chamber of the ECtHR found there to be no violation of Article 9 because the domestic court had undertaken an appropriate balancing exercise of the relevant interests in reaching their decision that the dismissal was fair.

Although the outcomes in these cases differed, they confirm that decisions by a religious ethos employer to dismiss or discipline staff for failing to comply with religious codes of conduct or life-style requirements can be justified, as long as all relevant factors are taken into account when undertaking the assessment of proportionality. Factors to weigh in the balance include the nature of the post, the interest in religious autonomy of the employer and the interests of staff members in a private life and freedom of religion and expression. Where the interests of the employee have been properly assessed, the ECtHR has been willing to uphold the religious autonomy rights of religious organisations by requiring loyalty to their teaching.

\section{Conclusion}

Since the Kokkinakis judgment in 1991, considerable progress has been made in promoting

\footnotetext{
${ }^{33}$ Fernandez Martinez v. Spain, Application No. 56030/07, judgment of 15 May 2012.

${ }^{34}$ Siebenhaar v. Germany, Application No. 18136/02, judgment of 3 February 2011.
} 
the protection of freedom of religion or belief in the employment context, in particular with the decision in Eweida that the freedom to resign does not preclude the protection of Article 9 from the workplace, and that the 'manifestation' of religion or belief should be understood more inclusively.

Nonetheless, the scope of the protection for individual freedom of religion or belief at work does remain subject to the significant restrictions which arise courtesy of the wide margin of appreciation used in religion or belief cases. This allows very substantial variance in protection for religion or belief in the workplace across Europe. ${ }^{35}$ For example, religious symbols are routinely accepted in the UK and routinely rejected in France. This suggests that more needs to be done to create equal levels of protection for religion and belief across the Strasbourg jurisdiction.

It remains open to question whether stronger protection for religion or belief at work is likely to develop in future. The use of a very wide margin of appreciation looks set to continue in religion or belief cases, as seen in cases such as S.A.S v. France. ${ }^{36}$ Moreover, a wide range of sensitive issues involving religion and belief are currently coming before the courts, relating to matters such as social ethics on which there is little agreement within or between states. This means that the ECtHR may well be reluctant to undertake stronger standard setting across Europe on religion and belief matters for some time. This is made more likely given the rather similar approach taken to the same issues by the Court of Justice of the European union (CJEU) in the recent Achbita ${ }^{37}$ and Bougnaoui ${ }^{38}$ cases, where Europe's other supranational court accepted similar limits on religious expression in the workplace as Ebrahimian. The fact that the CJEU could legitimately claim that its decision accords with the ECHR case law demonstrates again the residual weakness of protection for religion and belief in the workplace.

Thus, although progress has been made since Kokkinakis, an essential weakness remains in the failure of the ECtHR to set universal standards in the protection of freedom of religion or belief, allowing instead for national context to be given significant weight in determining levels of protection for fundamental rights.

\footnotetext{
35 See Tobias Lock, 'Religious Freedom and Belief Discrimination in Germany and the United Kingdom: Towards a Common European Standard?', 38(5) European Law Review (2013), pp. 655-676.

${ }^{36}$ S.A.S v. France, Application No. 43835/11, judgment of 1 July 2014.

${ }^{37}$ Achbita v. G4S Secure Solutions, Case C-157/15.

${ }^{38}$ Bougnaoui v. Micropole, Case C-188/15.
} 